\title{
The Relationship Between Willingness to Communicate and English Language Proficiency
}

\author{
Fithrotul Khoiriyah* \\ Graduate School \\ Universitas Negeri Yogyakarta \\ Yogyakarta, Indonesia \\ fithrotulkhoiriyah.2018@student.uny.ac.id
}

\begin{abstract}
One of the effective aspects assumed in influencing student success in foreign language learning is the Willingness to Communicate (WTC). This correlational study was intended to explore any possible relationship between students' willingness to communicate and English Language Proficiency. The participants of this study were 23 Graduate students majoring in English Language Education at Yogyakarta State University. The instrument was a questionnaire of Willingness to Communicate in a Foreign Language Scale (WTC-FLS) developed and also validated by Baghaei (2012). It consisted of 20 items with a five-point Likert scale. The validity of the questionnaire was acceptable, while the reliability was 0.899 . Moreover, the study used the score of students' ProTEFL (Proficiency Test of English as a Foreign Language) as a measure of their English Language Proficiency. For data analysis, it employed A Person Product-moment Correlation analysis. The analysis result revealed that there was no correlation between Willingness to Communicate and English language proficiency. It showed that students who had a high score of English language Proficiency did not always have the willingness to communicate in English or vice versa.
\end{abstract}

Keywords-Willingness to Communicate (WTC), English Language Proficiency

\section{INTRODUCTION}

Many scholars have defined language in diverse ways. Those definitions include the specific function of language, which is as a means of communication (Halliday, 1973; Pinker, 1994; and Brown, 2007). By the role of language, the language learners should practice by using the language for their communication. Relating to foreign language teaching and learning, MacIntyre, Clement, Dornyei, and Noels (1998) suggests that the main purpose of second or foreign language learning is to "engender in language students the willingness to seek out communication opportunities and the willingness actually to communicate in them" (p.547). By this belief, MacIntyre et al. (1998) proposed the willingness to communicate as an appropriate goal for second language education.

This concept of L2 willingness to communicate was originally related to the concept of L1 willingness to communicate (L1 WTC). In the late 1950s and early 60s, the WTC concept appeared based on the work on communication

\author{
Dyah Setyowati Ciptaningrum \\ Graduate School \\ Universitas Negeri Yogyakarta \\ Yogyakarta, Indonesia \\ dyah_ciptaningrum@uny.ac.id
}

in the native language (McCroskey \& Richmond, 1990). There is a difference in communication behaviors in a society where some people do not want to communicate much, and even others can talk well. This communication concept was then known as "willingness to communicate" (WTC). McCroskey and Baer in 1985 defined this concept as "a stable predisposition toward communication when free to choose to do so" (as cited in MacIntyre \& Charos, 1996, p. 7).

The WTC concept was intellectualized as the cognitive process of volitional choosing to speak, which is decided by the individual's personality (McCroskey \& Richmond, 1990). Then, McCroskey states that L1 WTC is highly reliant on two main antecedents which are Communication Apprehension and Self-Perceived Communication Competence (McCroskey, 1997). Communication Apprehension or CA is "an individual's level of fear or anxiety associated with either real or anticipated communication with another person or persons" (McCroskey, 1997, p. 82). People who have CA are less willing to communicate. Then, Self-Perceived Communication Competence or SPCC is related to the view of the individual's ability to communicate.

Based on the model of L1 WTC of McCroskey and Baer in 1985, MacIntyre and his colleagues developed the pyramidfigure model of L2 WTC in 1998. The concept of L2 WTC was described as "a readiness to enter into discourse at the particular time with a specific person or persons using L2" (MacIntyre et al., 1998, p 547). This concept implies that language learners do not only need a deep linguistic competence, but they also must attempt to engage in communicative competence in English. Here, WTC represents as the direct factor inciting language learners to use English communicatively (Aubrey, 2011). L2 WTC model highlights that if learners are willing to communicate, usually they will try to find the chance to engage in a L2 conversation. Pyramid model of L2 WTC designed by MacIntyre is presented in Figure 1.

The model or L2 WTC consists of six-layer with 12 variables. There are two primary levels. Level one includes variables of situational factors (Layer 1-3), and level two includes variables of individual factors (layer 4-6). The first level or situational factors are subject to change. It means that 
these variables are influenced by the particular context at a specific time. These situational factors of L2 WTC consist of L2 use, Willingness to communicate, Desire to communicate with a specific person, and State Communicative SelfConfidence. Then, for the individual variables, they are considered as more stable properties of the person and can be employed in any situation. These factors consist of Interpersonal Motivation, Intergroup motivation, Seflconfidence, Intergroup Attitude, Social Situation, Communicative competence, Intergroup Climate, and Personality. Either situational factor or individual factors can increase or decrease L2 WTC (MacIntyre, 2007).

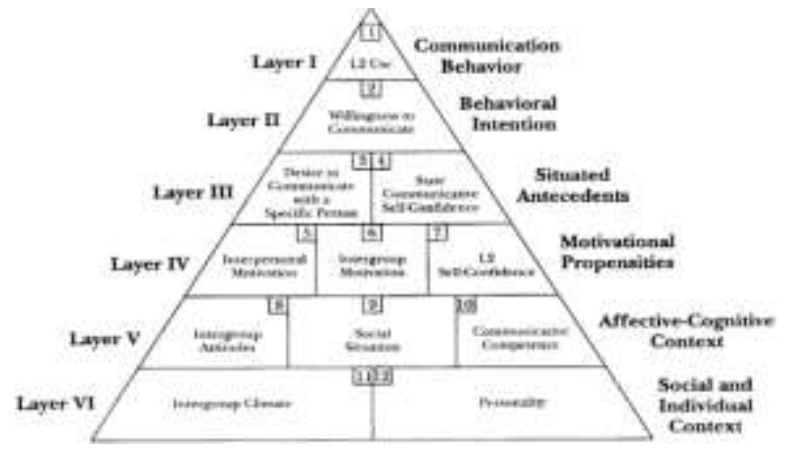

Fig 1. Heuristic model of L2 WTC (cited in MacIntyre, Clement, Dornyei, \& Noel, 1998, p. 547)

In addition, MacIntyre et al. (1998) stated that their model of L2 WTC above could be beneficial for practically and pedagogically rationalizing the individuals' differences relating to WTC. This model is also significant for the success of SLA development. The L2 WTC model becomes vital since it was the "first attempt at a comprehensive treatment of WTC in the L2" (p.588). By this reason, the L2 WTC model of MacIntyre et al. (1998) is still considered the most powerful, influential and also comprehensive for WTC research.

In the last two decades, the research on willingness to communicate became one of the prevalent topics in second language acquisition, especially investigating the factors influencing the willingness to communicate in English as the second language in Western countries (e.g., Baker \& MacIntyre, 2000; MacIntyre et al., 2002). MacIntyre et al. (1998) argued that a person's communication confidence in L2 or EFL as the target language has ranged from $0 \%$ to $100 \%$. Commonly, most people who possess a high level of communicative competence in L1 usually they will stay silent in EFL class. While those people who dislike engaging in L1 communication, at some point, they possess higher WTC in EFL classes. For these reasons, many scholars have conducted research related to the factors affecting WTC levels. Those factors or antecedents are communication anxiety, motivation, self-perceived communication competence, self-confidence, personality, content, and context covering opposite sex, familiarity, learners' mood, learners' cohesiveness, task-type in classroom, teachers' support and role, classroom acoustics, learners' fear for making mistakes, etc. (House, 2004; Cao, 2009, Cao \& Phill, 2006, Zeng, 2010, Riasati and Nooreen, 2011; Behzad et al., 2013).
Lately, in the context of English as foreign language learning (EFL), especially in Asia, some studies (e.g., Yashima, 2002; Yashima et al., 2004) have been conducted relating to the willingness to communicate. In this EFL context, language learners do not have linguistic needs or obligations for using English in their daily life. Moreover, in the Indonesian EFL context, the research investigating WTC is still at an emerging stage. Several studies examined anxiety and willingness to communicate (Muamaroh \& Prihartanti, 2013; Rastegar \& Karami, 2015). Muamaroh and Prihartanti's (2013) study indicated that Indonesian learners' willingness to communicate was very low, and anxiety became the leading cause of students' willingness to communicate. Wijaya and Rizkina (2015) examined four factors that caused students' willingness to communicate, such as task-type, class-size, language anxiety, and teacher-students' rapport. Those previous studies about L2 WTC in Indonesia mostly investigated the relationship between anxiety and willingness to communicate.

Nevertheless, there is still a limited study that examined the relationship between students' willingness to communicate and their English achievement. In the Indonesian context, most students learn English with the goal that they can speak English fluently. Unfortunately, many learners cannot reach this goal even though they have good English proficiency. It is also possible for the opposite point that learners who do not have good proficiency; they are very willing to communicate using English. Thus, this study aimed to investigate the relation between Willingness to Communicate and English proficiency.

\section{METHOD}

\section{A. Research Design}

The research type of this study was the quantitative descriptive approach in the form of correlational study, which showed the result in a numerical form. The correlational research "involves collecting data to determine whether, and to what degree, a relationship exists between two or more quantifiable variables" (Gay, Mills, \& Airasian, 2009, p. 204). The correlational study presents the extent of change in one variable affected by the change in another variable (Ary et al., 2002, p. 143). Relating to this research, the focus of this study was on examining the relationship between willingness to communicate in English and English language proficiency.

\section{B. Participants}

The research took place at Yogyakarta State University. The participants of this study were 23 graduate students (both male and female), majoring in English Language Education study program. The table below shows the participants' gender in this study.

\begin{tabular}{|c|c|}
\hline \multicolumn{2}{|c|}{ Gender } \\
\hline Female & 15 \\
\hline Male & 8 \\
\hline Total & 23 \\
\hline
\end{tabular}




\section{Research Instrument}

This research used two instruments. For analyzing Willingness to Communicate of students, this research employed Willingness to Communicate in a Foreign Language Scale (WTC-FLS) developed and also validated by Baghaei (2012). This instrument consisted of three subscales, which measure: a. Willingness to communicate with native speakers (WTC-NS), b. Willingness to communicate with the foreign person who is a non-native speaker of English (WTC-NN), and c. Willingness to communicate in the school context (WTCSC). The scale contained 20 items with a five-point Likert scale which ranged from strongly disagree to strongly agree. For the validity of this instrument, it had an acceptable result of validity by using the Person product moment test. It showed that $r$ values were higher than the $r$ table $(r$ table $=0.413$ with $\mathrm{N}$ is 23). For the reliability of instrument WTC-FLS with 20 items by using Cronbach's Alpha, it was 0.899 . The reliability of each subscale of WTC is also presented in the table below. Then, for English language proficiency, it used ProTEFL score from each of the participants which they received when entering the university.

TABLE I. RELIABILITY OF WTC-FLS

\begin{tabular}{|r|r|}
\hline \multicolumn{2}{|c|}{ Reliability Statistics } \\
\hline $\begin{array}{c}\text { Cronbach's } \\
\text { Alpha }\end{array}$ & N of Items \\
\hline .899 & 20 \\
\hline
\end{tabular}

TABLE II. RELIABILITY OF EACH SUBSCALE OF WTC

\begin{tabular}{|c|r|r|}
\hline Scale & \multicolumn{1}{|c|}{ N of items } & \multicolumn{1}{c|}{ Reliability } \\
\hline WTC-FLS & 20 & 0.899 \\
\hline WTC-NS & 6 & 0.836 \\
\hline WTC-NN & 6 & 0.743 \\
\hline WTC-SC & 8 & 0.863 \\
\hline
\end{tabular}

\section{Data Collection Technique}

For collecting the data, here are some steps which were taken, as follows:

- Distributing the questionnaire of Willingness to Communicate (WTC) to the students and asked for the ProTEFL score from each students. Before distributing those questionnaires, the researcher gave instructions on how to answer and also ask the students to answer the survey faithfully.

- Collecting back the polls and ProTEFL score.

- Providing information to the participants that the data from the questionnaire would be kept secretly because it was correlated with the ethics of research which all names of participants should be a pseudonym. Then, giving info that the result of the questionnaire would not affect the student's score of English.

\section{E. Data Analysis Technique}

This research used the product-moment correlation coefficient or Pearson $r$ as the method of analysis because it is the most common technique for correlational research. Gay, Mills, \& Airasian (2009) argued that Person r is a "measure of correlation that is appropriate when both variables to be correlated are expressed as continuous (i.e., ratio or interval) data" (p. 210). For analyzing the data taken from the participants, here are some steps, as follows:

- Inputting the data collected from WTC-FLS and ProTEFL scores.

- Computing the correlation between willingness to communicate and English proficiency using ProTEFL score by SPSS.

- Interpreting correlational results based on Pearson's correlation (two-tailed).

- Representing the conclusion of the analysis results.

\section{RESULT AND DISCUSSION}

This part would present the analysis result and discussion of this research. This research aimed to know the relation between Willingness to communicate and English language proficiency. The table below presents the analysis result of the correlation coefficient between Willingness to Communicate (WTC) and English language proficiency using ProTEFL score.

TABLE III. CORRELATION BETWEEN WTC-FLS AND ENGLISH LANGUAGE PROFICIENCY

\begin{tabular}{|c|c|r|r|}
\hline \multicolumn{4}{|c|}{ Correlations } \\
\hline \multirow{3}{*}{ WTC } & Pearson Correlation & \multicolumn{1}{|c|}{ WTC } & ProTEFL \\
\cline { 2 - 4 } & Sig. (2-tailed) & 1 & .214 \\
\cline { 2 - 4 } & $\mathrm{N}$ & 23 & .328 \\
\hline ProTEFL & Pearson Correlation & .214 & 23 \\
\cline { 2 - 4 } & Sig. (2-tailed) & .328 & 1 \\
\cline { 2 - 4 } & $\mathrm{N}$ & 23 & 23 \\
\hline
\end{tabular}

The table above shows there was no significant correlation between Willingness to Communicate and English language proficiency $(\mathrm{r}=0.214, \mathrm{n}=23, \mathrm{p}>0.05)$. For the relation between each subscale of WTC and English proficiency will be presented as follow.

TABLE III. CORRELATION BETWEEN WTC-NS AND ENGLISH LANGUAGE PROFICIENCY

\begin{tabular}{|c|c|r|r|}
\hline \multicolumn{4}{|c|}{ Correlations } \\
\hline \multicolumn{1}{|c|}{} & \multicolumn{1}{|c|}{ ProTEFL } & \multicolumn{1}{|c|}{ WTC-NS } \\
\hline ProTEFL & $\begin{array}{c}\text { Pearson } \\
\text { Correlation }\end{array}$ & 1 & .278 \\
& Sig. (2-tailed) & & .199 \\
\cline { 2 - 4 } & $\mathrm{N}$ & 23 & 23 \\
\hline \multirow{3}{*}{ WTC-NS } & $\begin{array}{c}\text { Pearson } \\
\text { Correlation }\end{array}$ & .278 & 1 \\
& Sig. (2-tailed) & .199 & \\
\cline { 2 - 4 } & $\mathrm{N}$ & 23 & 23 \\
\cline { 2 - 4 } & & & \\
\end{tabular}


From the table above, it indicated that there was no significant correlation among Willingness to Communicate with Native Speaker (WTC-NS) and English language proficiency. $(\mathrm{r}=0.278, \mathrm{n}=23, \mathrm{p}>0.05)$.

TABLE IV. CORRELATION BETWEEN WTC-NN AND ENGLISH LANGUAGE PROFICIENCY

\begin{tabular}{|c|c|c|c|}
\hline \multicolumn{4}{|c|}{ Correlations } \\
\hline & & ProTEFL & $\begin{array}{l}\text { WTC- } \\
\text { NN }\end{array}$ \\
\hline \multirow[t]{3}{*}{ ProTEFL } & $\begin{array}{c}\text { Pearson } \\
\text { Correlation }\end{array}$ & 1 & .257 \\
\hline & Sig. (2-tailed) & & .237 \\
\hline & $\mathrm{N}$ & 23 & 23 \\
\hline \multirow[t]{3}{*}{ WTC-NN } & $\begin{array}{c}\text { Pearson } \\
\text { Correlation }\end{array}$ & .257 & 1 \\
\hline & Sig. (2-tailed) & .237 & \\
\hline & $\mathrm{N}$ & 23 & 23 \\
\hline
\end{tabular}

The table above presents that there was no significant correlation among Willingness to Communicate with NonNative speaker (WTC-NN) and English language proficiency. $(\mathrm{r}=0.257, \mathrm{n}=23, \mathrm{p}>0.05)$.

TABLE V. CORRELATION BETWEEN WTC-SC AND ENGLISH LANGUAGE PROFICIENCY

\begin{tabular}{|c|c|r|r|}
\hline \multicolumn{4}{|c|}{ Correlations } \\
\hline \multirow{7}{*}{ ProTEFL } & $\begin{array}{c}\text { Pearson } \\
\text { Correlation }\end{array}$ & ProTEFL & TOTALSC \\
\cline { 2 - 4 } & $\begin{array}{c}\text { Sig. (2- } \\
\text { tailed) }\end{array}$ & & .060 \\
\cline { 2 - 4 } & $\mathrm{N}$ & 23 & .787 \\
\hline TOTALSC & $\begin{array}{c}\text { Pearson } \\
\text { Correlation }\end{array}$ & .060 & 23 \\
\cline { 2 - 4 } & $\begin{array}{c}\text { Sig. (2- } \\
\text { tailed) }\end{array}$ & .787 & 1 \\
\cline { 2 - 4 } & $\mathrm{N}$ & 23 & 23 \\
\hline
\end{tabular}

From the table above, it presents that there was no significant correlation among Willingness to Communicate in School Context (WTC-SC) and English language proficiency. $(\mathrm{r}=0.060, \mathrm{n}=23, \mathrm{p}>0.05)$.

The result of Pearson's correlation above showed that there was no correlation between Graduate students' WTC and English language proficiency. The correlation coefficients among the subscale of WTC and English proficiency also indicated that there was no relation. Those subscales of WTC were the willingness to communicate with Native Speaker (WTC-NS), willingness to communicate with Non-Native speaker (WTC-NN) and also willingness to communicate in School Context (WTC-SC).

This research result indicated that the willingness to communicate of Graduate students majoring in English Department had low relation to their English language proficiency, which presented by the Pro-TEFL score. It represented that students who had a high score of L2 achievement did not always have willing to communicate in
English or vice versa. Dörnyei (2003) stated that there were numerous L2 students who were extremely skilled L2 speakers; however, they would generally stay away from L2 communication competence, though some other, less capable students effectively look for chances to take part in L2 talk (p.12). Moreover, Baghaei, Dourakhshan, and Salavati (2012) added that WTC of foreign language did not intensely correlate with the success of English language learning.

The results of the relationship between students' willingness to communicate with non-native speaker and English proficiency were in line with the result of previous studies from Baghaei, Dourakhshan, and Salavati (2012) and Mahmoodi and Moazam (2014). For the study conducted by Baghaei, Dourakhsan, and Salavati (2012), they investigated the correlation between WTC and English proficiency of Iranian learners. They found that only two subscales of WTC, WTC-NS and WTC-SC, had a positive correlation with English proficiency. However, there was almost no relation between willingness to communicate with the non-native speaker (WTC-NN) and English proficiency of Iranian learners. Moreover, Mahmoodi and Moazam (2014) examined the relationship between willingness to communicate and the L2 proficiency of Arabic language learners. They also found that only the WTC in the school context, which had a high correlation with students' willingness to communicate. For other subscales of WTC, such as WTC with a native speaker and WTC with a non-native speaker, they had no relation with students' language proficiency. Baghaei, Dourakhshan and Salavati (2012) suggested that students did not have the willingness to communicate with the non-native speaker because they thought that they could not learn much from that non-native speaker, so they would tend to unwilling for interacting with them (p. 12162).

Regarding this low relation between WTC and foreign language proficiency, this could be caused by some reasons. One example of the cause might be their opportunity to meet a native speaker or non-native speaker. Students infrequently have the chance to meet and communicate using English with a native or non-native speaker, especially in the context of outside the classroom. In the school context, they have more opportunity to interact using English. Unfortunately, even those students have the same chance to use English in the class; it will depend on the person who is willing to communicate or not. Concerning this, Dörnyei (2003) argued that the concept of WTC is a completely steady personality trait which advanced through the years, but the circumstance is progressively perplexing concerning L2 use, since the dimension of one's L2 capability, and especially the person's L2 communicative competence, become a supplementary influential changing variable (p.12).

Additionally, this study revealed that there is no correlation between willingness to communicate in the school context and foreign language proficiency. In the classroom context, some students would pretend not to communicate, or they would only talk if it was necessary or essential. One of the critical factors that caused this unwillingness to communicate is language anxiety. Some previous studies had investigated the 
relation among willingness to communicate and language anxiety, especially in the Indonesian context (Muamaroh \& Prihartanti, 2013; Wijaya \&Rizkina, 2013; and Manispuspika, 2018). Those studies revealed that language anxiety had a positive correlation to the students' willingness to communicate in the school context. Munispuspika (2018) stated that students who had language anxiety in their classrooms would be more apprehensive for using the second language and tended to be unwilling to communicate using a foreign language (p. 215). Ortega (2014) added that willingness to communicate in the second language could be predicted by two factors, which are communicative confidence in L2 and L2 attitude (p. 204). L2 communicative competence was affected by language anxiety and self-perceived competence (Ortega, 2014, p. 204). Thus, it implied that the willingness to communicate in the second language was influenced by many factors.

\section{CONCLUSION}

The research had the goal to examine the relationship between willingness to communicate (WTC) and English language proficiency. The research participants were 23 Graduate students majoring in English Department at Yogyakarta State University consisted of 15 females and eight males. For the research instrument, it applied Willingness to Communicate in a Foreign Language Scale (WTC-FLS) contained 20 items with a five-point Likert scale. The analysis used the method of correlational study and applied Person's correlation or Product moment correlation analysis. The results showed that there is no correlation between willingness to communicate and students' language proficiency, which was indicated $r$ value was 0.214 or $p>0.05$. This study also revealed that from each subscale of willingness to communicate, such as willingness to communicate with a native speaker (WTC-NS), willingness to communicate with the non-native speaker (WTC_NN) and willingness to communicate in the school context (WTC-SC) had no significant relation with English language proficiency. It means that high or low English proficiency does not correlate with student's intention or willingness to communicate in English. However, the research suggests that students who take the opportunity for interacting in the classroom can raise their willingness to communicate.

This research was only limited to analyze the relation between WTC and language proficiency. For further investigation, it will be necessary to investigate the factors which affect WTC, or they can conduct the study of the relationship between motivation and WTC of Indonesian learners or even teachers. Moreover, subsequent research can also investigate the willingness to communicate components individually, so it can reveal the degree of willingness to communicate, which affects the students' language proficiency of the second language. This research also can be an additional resource for everyone who interests in conducting the study of willingness to communicate in the second language.

\section{REFERENCES}

Ary, D., Jacobs, L.C., \& Razavieh, A. (2002). Introduction to research in education (6th ed). Wadsworth: Wadsworth Group.

Aubrey, S. (2011). Facilitating interaction in East Asian EFL classrooms: increasing students' willingness to communicate. Language Education in Asia, 2(2), 237-45.

Baghaei, P., Dourakhshan, A., \& Salavati, O. (2012). The relationship between willingness to communicate and success in learning English as a foreign language. Modern Journal of Applied Linguistics, 4(2), 53-67.

Baker, S. C., \& MacIntyre, P. D. (2000). The role of gender and immersion in communication and second language orientations. Language learning, 50(2), 311-341.

Behzad, G., Azar, H.F., Gholam Hassan, K2013. Examining the relationshipsbetween willingness to communicate ingEnglish, communication confidence, andclassroom environment. InternationalJournal of Research Studies inEducational Technology, 1: 1-10.

Brown, H. D. (2007). Principles of language learning and teaching. $5^{\text {th }}$ Ed. New York: Pearson-Longman.

Cao, Y., 2009. Temporal fluctuation insituational willingness to communicate ina second language classroom. New Zealand Studies in Applied Linguistics,12(2): 1-6.

Cao, Y. and J. Philp, 2006. Interactional context and willingness to communicate: A comparison of behaviour in whole class, group and dyadic interaction. System, 34:480-493.

Dörnyei, Z. (2003). Attitudes, orientations, and motivations in language learning: Advances in theory, research, and applications. Language learning, 53(S1), 3-32.

Gay, L. R., Mills, G. E., \& Airasian, P. W. (2009). Educational research: Competencies for analysis and applications, student value edition. Upper Saddle River, NJ: Merrill.

Halliday, M. A. K. (1973). Explorations in the Functions of Language. London: Edward Arnold.

House, A., 2004. Learner perceptions of willingness to communicate. Unpublished masteres thesis. The University of Auckland, Auckland, New Zealand.

MacIntyre, P. D., \& Charos, C. (1996). Personality, attitudes, and affect as predictors of second language communication. Journal of language and social psychology, 15(1), 3-26.

MacIntyre, P. D., Clément, R., \& Donovan, L. A. (2002, October). Willingness to communicate in the L2 among French immersion students. In second language research Forum, Toronto.

MacIntyre, P. D., Dörnyei, Z., Clément, R., \& Noels, K. A. (1998). Conceptualizing willingness to communicate in a L2: A situational model of L2 confidence and affiliation. The Modern Language Journal, 82(4), 545-562. Mahmoodi, M. H., \& Moazam, I. (2014). Willingness to communicate (WTC) and L2 achievement: The case of Arabic language learners. Procedia-Social and Behavioral Sciences, 98, 1069-1076.

Manipuspika, Y. S. (2018). Correlation between Anxiety and Willingness to Communicate in the Indonesian EFL Context.

McCroskey, J. C., \& Richmond, V. P. (1990). Willingness to communicate: Differing cultural perspectives. Southern Journal of Communication, 56(1), 72-77.

Muamaroh \& Prihartanti, N. (2013). Willingness to communicate in English: A case study of Indonesian University students. Kajian Linguistik dan Sastra, 25(1), 71-81.

Ortega, L. (2014). Understanding second language acquisition. Routledge.

Pinker, S. (1994). The language instinct. New York, NY, US: William Morrow \& Co.

Rastegar, M. \& Karami, M. (2015). On the Relationship between Foreign Language Classroom Anxiety, Willingness to Communicate and Scholastic Success among Iranian EFL Learners. Theory and Practice in Language Studies, 5(11), 2387-2394. 
Riasati, M.J. and N. Nooreen, 2011.Antecedents of willingness to communicate: A review of literature.Studies in Literature and Language, 3(2): 74-80.

Wijaya, H., \& Rizkina, P. A. (2015). Factors Affecting Students' Willingness to Communicate (A Case Study in Higher Education). In Proceedings of the 7th International Conference on Teaching English as a Foreign Language (COTEFL 7th) Faculty of Letters, University of Muhammadiyah Purwokerto, Central Java, Indonesia (pp. 16-17).
Yashima, T. (2002). Willingness to communicate in a second language: The Japanese EFL context. The Modern Language Journal, 86(1), 54-66.

Yashima, T., Zenuk-Nishide, L., \& Shimizu, K. (2004). The influence of attitudes and affect on willingness to communicate and second language communication. Language learning, 54(1), 119-152.

Zeng, M., 2010. Chinese students"e willingness to communicate in English in Canada. Unpublihsed doctoral dissertation. Windsor, Ontario: Canada. 